\title{
Alternating Dependency of Cytokinin Activity on the Number of Methylene Units in $\omega$-Phenylalkyl Derivatives of Some Purine Cytokinins and 4-Substituted Pyrido[3,4- $d$ ]pyrimidine
}

\author{
Shiro Nishikawa, Zenzaburo Kumazawa, Naoki KaShimura, \\ Yoshio Nishikimi and Shoji UEMURA \\ Laboratory of Pesticide Chemistry, Department of Agricultural Chemistry, \\ Mie University, Tsu, Mie 514, Japan
}

Received February 13, 1986

\begin{abstract}
$\omega$-Phenylalkyl derivatives of $N^{6}$-substituted adenine, $N^{6}$-substituted adenosine and 6-alkoxypurine with odd numbers of methylenes had relatively high activity, while the corresponding 2methyl-4-substituted-aminopyrido[3,4- $d$ ] pyrimidines with even numbers of methylenes had high activity in an Amaranthus betacyanin test and lettuce seed germination test. These results suggest that the $\omega$-phenyl groups of the cytokinins play a specific role for cytokinin-receptor binding and that the pyrido[3,4- $d]$ pyrimidines interact with a receptor in a different binding mode.
\end{abstract}

Such physical properties of a series of $\omega, \omega^{\prime}-$ dicarboxylic acids as melting point and solubility in water vary alternately with the increase of the number of methylenes. ${ }^{1)}$ Such an alternation has also been observed in biological systems. For instance, $\omega$-fluoro-substituted carboxylic acids ${ }^{1)}$ and substituted diphenyl ethers of $\omega, \omega^{\prime}$-glycol ${ }^{2}$ show a similar alternation in toxicity against mice and schistosomicidal activity, respectively. The former case belongs to metabolism in vivo, i.e., $\beta$-oxidation, while the latter one belongs, probably, to the intrinsic substrate-receptor interaction. The alternation of biological activity due to substrate-receptor interaction is interesting from the standpoint of a structure-activity study, since such a terminal functional group may play an important role in biological activity by a weak, but specific interaction with a group or groups of a receptor responsible for substraterecognition. Unfortunately, reasonable explanations for this alternation in biological systems have not been made.

Our efforts in recent several years have been directed to structure-activity studies of cytokinins, including both the purine type and

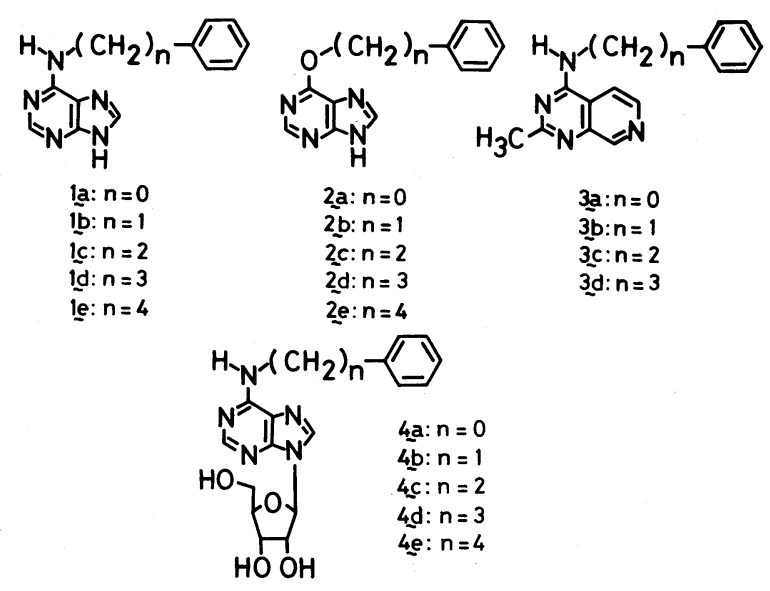


non-purine type, to reveal fundamental aspects of cytokinin-receptor interaction. ${ }^{3 \sim 7)}$ In the course of these studies, we have found an interesting alternation in the biological activity of both cytokinins. As far as we know, there has been no report on the alternation of cytokinin activity since the discovery of kinetin in 1955. In this paper, we report an alternating dependency on the even and odd numbers of methylene units in $\omega$-phenylakyl derivatives of $N^{6}$-substitutęd adenine (1), its riboside (4), 6alkoxypurine (2) and 2-methyl-4-substitutedaminopyrido[3,4- $d]$ pyrimidine (3).

\section{RESULTS}

\section{i) $\quad N^{6}-(\omega$-Phenylalkyl $)$ adenines (1)}

In an Amaranthus betacyanin test, 1a, 1b ( $N^{6}$-benzyladenine), 1c and 1e exhibited the activity expected from previous results in other bioassays. $^{8,9)}$ The activity of $\mathbf{1 d}$ was five times higher than that of 1c. Cytokinin activity decreased in the order of $1 \mathbf{b}>\mathbf{1 d}>\mathbf{1 a}>1 \mathrm{c} \gg \mathbf{1 e}$, compound 1e being inactive (Table I). The homologs with odd numbers of methylenes showed stronger activity than those with even numbers of methylenes. Therefore, these compounds exhibited an alternation of activity with respect to the methylene length (Fig. 1). In a lettuce seed germination test, the decreasing order of activity, $\mathbf{1 b}>\mathbf{1 d}>\mathbf{1 a}>\mathbf{1 c} \gg \mathbf{1 e}$, was observed, which coincided with that in the Amaranthus betacyanin test. Similar results were obtained in a tobacco callus test (Table II).

ii) 6-( $\omega$-Phenylalkoxy)purines (2)

6-Alkoxypurines are relatively potent cytokinins that have oxygen linkage in the 6position. ${ }^{10,11)}$ Compounds $2 \mathbf{a} \sim \mathbf{2 e}$ with $0 \sim 4$ methylenes were bioassayed to learn whether or not such an alternation could be observed for these purine derivatives. In both an $\mathrm{Ama}$ ranthus betacyanin test and lettuce seed germi-

Table I. Summary of the Cytokinin Activity of $\omega$-Phenylalkyl Derivatives of $N^{6}$-Substituted ADENINE, 6-ALKOXYPURINE, 2-METHYL-4-SUBSTITUTED-AMINOPYRIDO[3,4- $d$ ]PYRIMIDINE AND $N^{6}$-Substituted AdEnOSINE

\begin{tabular}{|c|c|c|c|c|}
\hline \multirow{2}{*}{ Compound } & \multicolumn{2}{|c|}{ Betacyanin biosynthesis } & \multicolumn{2}{|c|}{ Lettuce seed germination } \\
\hline & $\mathrm{C}_{0.1 \mu \mathrm{MBA}},{ }^{a} \mu \mathrm{M}$ & $\mathrm{pC}_{0.1 \mu \mathrm{MBA}}$ & $\mathrm{E}_{50},{ }^{b} \mu \mathrm{M}$ & $\mathrm{pE}_{50}$ \\
\hline $1 \mathbf{a}$ & 0.48 & 0.32 & 0.74 & 0.13 \\
\hline 1b & 0.10 & 1.00 & 0.10 & 1.00 \\
\hline 1c & 0.89 & 0.05 & 2.5 & -0.39 \\
\hline 1d & 0.16 & 0.79 & 0.40 & 0.40 \\
\hline 1e & Inactive & & Inactive & \\
\hline $2 \mathbf{a}$ & 309 & -2.49 & 154 & -2.19 \\
\hline $2 \mathbf{b}$ & 0.33 & 0.48 & 0.19 & 0.71 \\
\hline $2 c$ & 9.3 & -0.97 & 20.9 & -1.32 \\
\hline 2d & 0.71 & 0.15 & 0.66 & 0.18 \\
\hline $2 \mathbf{e}$ & Inactive & & Inactive & \\
\hline 3a & 2.5 & -0.40 & 0.81 & 0.09 \\
\hline $\mathbf{3 b}$ & 380 & -2.58 & Inactive & \\
\hline $3 c$ & 89 & -1.95 & Inactive & \\
\hline 3d & Inactive & & Inactive & \\
\hline $4 \mathbf{a}$ & 1.55 & -0.19 & 0.98 & 0.01 \\
\hline $4 b$ & 0.16 & 0.81 & 0.08 & 1.10 \\
\hline $4 c$ & 2.1 & -0.32 & 6.9 & -0.84 \\
\hline $\mathbf{4 d}$ & 0.25 & 0.60 & 0.20 & 0.70 \\
\hline $4 e$ & 45 & -1.65 & Inactive & \\
\hline
\end{tabular}

a Concentration at which the sample formed the same amount of betacyanin $\left(\Delta \mathrm{Abs}{ }_{542 \sim 620 \mathrm{~nm}}\right)$ as that of $0.1 \mu \mathrm{M}$ BA.

${ }^{b}$ Concentration at which the sample showed $50 \%$ germination after 4 days incubation at $31( \pm 1)^{\circ} \mathrm{C}$ in the dark. 
Table II. Cytokinin Activity of $N^{6}$ $(\omega$-PhenYlalkyl)adenines AND Their Ribosyl Derivatives IN a Tobacco Callus Test

\begin{tabular}{ccc}
\hline Compound & $\mathrm{C}_{\mathrm{K}},{ }^{a} \mu \mathrm{M}$ & $\mathrm{pC}_{\mathrm{K}}$ \\
\hline $\mathbf{1 a}$ & 0.12 & 0.92 \\
$\mathbf{1 b}$ & 0.013 & 1.90 \\
$\mathbf{1 c}$ & 0.54 & 0.27 \\
$\mathbf{1 d}$ & 0.12 & 0.92 \\
$\mathbf{1 e}$ & Inactive & \\
$\mathbf{4 a}$ & - & - \\
$\mathbf{4 b}$ & 0.057 & 1.24 \\
$\mathbf{4 c}$ & 0.53 & 0.27 \\
$\mathbf{4 d}$ & 0.19 & 0.72 \\
$\mathbf{4}$ & 13 & -1.10 \\
\hline
\end{tabular}

a Concentration at which the sample gave the same yield (fresh weight) as half of the maximum yield promoted by kinetin.

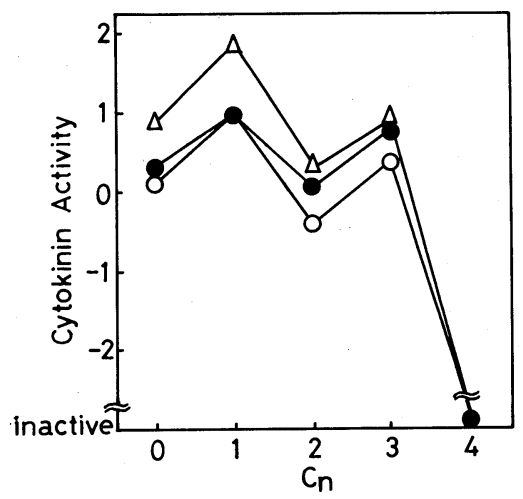

FIG. 1. Alternation of Cytokinin Activity of $N^{6}$ ( $\omega$-Phenylalkyl)adenines.

- - Amaranthus betacyanin test $\left(\mathrm{pC}_{0.1 \mu \mathrm{MBA}}\right) ; \bigcirc-\bigcirc$, lettuce seed germination test $\left(\mathrm{pE}_{50}\right) ; \triangle-\triangle$, tobacco callus test $\left(\mathrm{pC}_{\mathrm{K}}\right)$.

nation test, the activity decreased in the order of $\mathbf{2 b}>\mathbf{2 d}>\mathbf{2 c}>\mathbf{2 a} \gg \mathbf{2 e}$, $\mathbf{2 e}$ being inactive. Compound $\mathbf{2 d}$ was more active than $\mathbf{2 c}$ by a factor of approximately ten in the former test, and by a factor of three in the latter test. Additionally, 2a was less active than 2d. Irrespective of the different linkage in the 6position, 2 showed the same type of alternation as that observed for 1 (Fig. 2).

iii) 2-Methyl-4-( $\omega$-phenylalkylamino $)$ pyrido[3,4-d]pyrimidines (3)

The cytokinin activity of 4-substituted

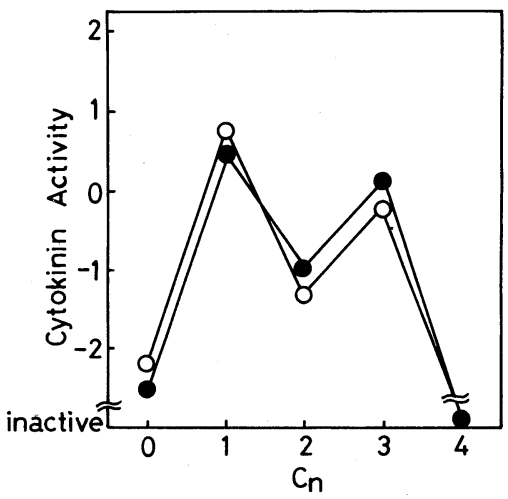

FIG. 2. Alternation of Cytokinin Activity of 6- $(\omega-$ Phenylalkoxy)purines.

- - Amaranthus betacyanin test $\left(\mathrm{pC}_{0.1 \mu \mathrm{MBA}}\right) ; \mathrm{O}-\mathrm{O}$, lettuce seed germination test $\left(\mathrm{pE}_{50}\right)$.

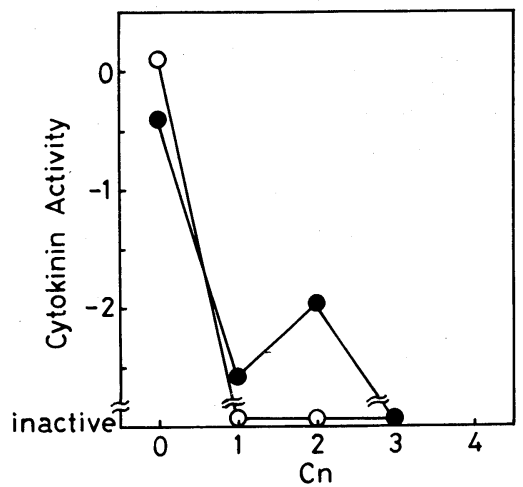

FIG. 3. Alternation of Cytokinin Activity of 2-Methyl-4( $\omega$-Phenylalkylamino)pyrido[3,4- $d]$ pyrimidines.

- - Amaranthus betacyanin test $\left(\mathrm{pC}_{0.1 \mu \mathrm{MBA}}\right) ; \bigcirc-\bigcirc$, lettuce seed gremination test $\left(\mathrm{pE}_{50}\right)$.

pyrido[3,4- $d]$ pyrimidines was first found in our systematic studies on pyridopyrimidines, i.e., 1,3-X-triazanaphthalenes $(X=5,6,7$ and 8). ${ }^{6,7,12)}$ The activity of $\mathbf{3 a} \sim \mathbf{3 d}$ was studied to compare with that of purine cytokinins 1 and 2. In the Amaranthus betacyanin test, the phenylamino derivative 3a was the most active, and $\mathbf{3 c}$ was thirty-five times less active than $3 \mathbf{a}$, but four times more active than the benzylamino derivative $\mathbf{3 b}$. Compound $\mathbf{3 d}$ was inactive. Thus, the activity decreased in the order of $\mathbf{3 a}>\mathbf{3} \mathbf{c}>\mathbf{3 b}>\mathbf{3 d}$. The difference of activity between $\mathbf{3 b}$ and $\mathbf{3 c}$ was ascertained by several repetitions of the assay. The homologs 


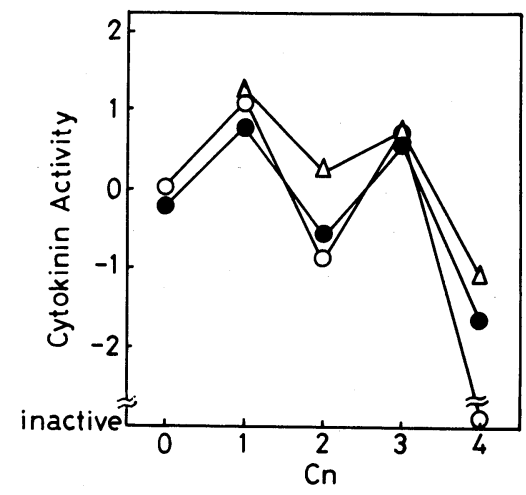

FIG. 4. Alternation of Cytokinin Activity of $N^{6}-(\omega-$ Phenylalkyl)adenosines.

- - Amaranthus betacyanin test $\left(\mathrm{pC}_{0.1 \mu \mathrm{MBA}}\right) ; \bigcirc-\bigcirc$, lettuce seed germination test $\left(\mathrm{pE}_{50}\right) ; \triangle-\triangle$, tobacco callus test $\left(\mathrm{pC}_{\mathrm{K}}\right)$.

with even numbers of methylenes showed higher activity than those with odd numbers of methylenes, which was quite different from the alternation of the purine cytokinins $\mathbf{1}$ and $\mathbf{2}$ (Fig. 3). In the lettuce seed germination test, only 3a was active.

\section{iv) $N^{6}-(\omega$-Phenylalkyl $)$ adenosines (4)}

In the Amaranthus betacyanin test, cytokinin activity decreased in the order of $\mathbf{4 b}>$ $\mathbf{4 a}>\mathbf{4 d}>\mathbf{4 c}>\mathbf{4 e}$, the decreasing order being consistent with that of the corresponding bases 1 (Fig. 4). The lettuce seed germination test and tobacco callus test gave the same results.

\section{DISCUSSION}

An alternation of cytokinin activity of $N^{6}$ ( $\omega$-phenylalkyl)adenines (1), which had been extensively studied in 1950s, was found for the first time in three different bioassays: an Amaranthus betacyanin test, lettuce seed germination test and tobacco callus test. Kuraishi earlier reported that 1a and 1c were almost as active as $\mathbf{1 b}$, and $\mathbf{1 d}$ was weak in promoting leaf growth of Raphanus sativus. ${ }^{8}$ ) Furthermore, Skinner et al. reported that $\mathbf{1 b}, \mathbf{1 c}$ and $\mathbf{1 d}$ were equally active in stimulating seed germination in a variety of lettuce.9) The results obtained in this study did not coincide with the previous results. The discrepancy, particularly in the order of activity between 1c and 1d may have arisen from the difference in accuracy or sensitivity of the assay methods.

$N^{6}$-( $\omega$-Phenylalkyl)adenosines (4) showed a similar alternation. This is reasonable since $N^{6}$-substituted adenines and their ribosyl derivatives exert similar substituent effects on cytokinin activity. ${ }^{13)}$ 6-( $\omega$-Phenylalkoxy)purines (2) also exhibited the same type of alternation, as expected from their structural resemblance to $\mathbf{1}$; the benzyloxy derivative $\mathbf{2 b}$ was the most active, as reported earlier. ${ }^{10,11)}$ Such an alternation of cytokinin activity of closely related 6-( $\omega$-phenylalkylthio)purines can be found in the literature, ${ }^{9)}$ the homologs with odd numbers of methylenes having stronger activity. These results imply that the four kinds of purine derivatives exert their cytokinin action similarly, irrespective of the linkage in the 6-position.

In contrast, 2-methyl-4-( $\omega$-phenylalkylamino)pyrido[3,4- $d]$ pyrimidines (3), a nonpurine type of cytokinin, exhibited an alternation different from that of the purine type of cytokinin. The present study and the previous one ${ }^{7)}$ show that the substituent effects were not the same between the pyrido[3,4- $d]$ pyrimidines and the purine cytokinins, suggesting different modes of interaction with a receptor for these two types of cytokinins.

Among $\quad N^{6}-(\omega$-substituted-alkyl)adenines, 1 with a phenyl group as the $\omega$-substituent showed alternation, while $N^{6}-(\omega$-hydroxyalkyl)adenines, $N^{6}$-n-alkyladenines, $N^{6}$-isoalkyladenines and $N^{6}$-alkoxyalkyladenines did not. ${ }^{12)}$ Thus, we believe at present that the $\omega$-phenyl group and the purine ring or the pyrido[3,4- $d]$ pyrimidine ring which interact with a receptor simultaneously (multiple recognition by the receptor) are necessary for the alternation of activity. The necessity of a planar phenyl group for potent cytokinin activity, which ensures favorable interaction with the receptor, has been found for 6-styrylpurines and their related compounds. ${ }^{5)}$ From the results in a gas chromatographic study of acyclic and cyclic hydrocarbons, Endo et $a l .{ }^{14)}$ have recently proposed a "structure 
similarity hypothesis" that claims compounds or groups having similar structures interact preferably with each other. The alternation in cytokinin activity specific for the $\omega$-phenylalkyl derivatives of the cytokinins, and the preferable interaction between structurally similar groups, strongly suggest that the substituent recognition site of the cytokinin receptor(s) in Amaranthus cotyledons, lettuce seed and tobacco callus has an aromatic planar nature.

$\omega$-Phenylalkyl derivatives of $\mathbf{1}, \mathbf{2}, \mathbf{3}$ and 4, which have specific substituent effects on cytokinin activity, are helpful for understanding the cytokinin-receptor interaction at the molecular level. Furthermore, these compounds may be used for distinguishing the true cytokinin binding proteins responsible for the activity from non-specific binding proteins, since the alternation is not related to their lipophilicity but is related to the three-dimensional structure of the receptor(s).

\section{EXPERIMENTAL}

General. Melting points (mp) are uncorrected. IR and UV spectra were recorded on a JASCO IR-G spectrophotometer and a Hitachi UV 200-10 spectrophotometer, respectively. ${ }^{1} \mathrm{H}-\mathrm{NMR}$ spectra were measured with a Hitachi R-22 spectrometer using $\mathrm{Me}_{4} \mathrm{Si}$ as an internal standard. Elemental analyses were performed at the Analytical Center of Kyoto University, Kyoto.

The following $N^{6}$-substituted adenines were synthesized by refluxing 6-chloropurine with appropriate amines together with triethylamine in 1-butanol for $3 \sim 5 \mathrm{hr}$, and were recrystallized from ethanol: $N^{6}$-phenyladenine (1a), mp $277 \sim 280^{\circ} \mathrm{C}$ (lit. ${ }^{15)} 284 \sim 285^{\circ} \mathrm{C}$ ), $70 \%$ yield; $N^{6}-(2-$ phenylethyl)adenine (1c), mp $225 \sim 227^{\circ} \mathrm{C}$ (lit. ${ }^{16)} 239 \sim$ $240^{\circ} \mathrm{C}$ ), $87 \% ; N^{6}$-(3-phenylpropyl)adenine (1d), mp $185^{\circ} \mathrm{C}$ (lit. ${ }^{16)} 161 \sim 164^{\circ} \mathrm{C}$ ), $51 \%$; and $N^{6}$-(4-phenylbutyl)adenine (1e), mp $158 \sim 164^{\circ} \mathrm{C}$ (lit. ${ }^{16)} 161 \sim 164^{\circ} \mathrm{C}$ ), $65 \%$. Similarly, the following 9-ribosyl derivatives were prepared from 6 chloro-9- $\beta$-D-ribofuranosylpurine: $\quad N^{6}$-phenyladenosine (4a), mp 196 $\sim 197^{\circ} \mathrm{C}$ (from aqueous methanol, lit. ${ }^{17)}$ $199^{\circ} \mathrm{C}$ ), $63 \%$; $N^{6}$-benzyladenosine (4b), mp $167 \sim 168^{\circ} \mathrm{C}$ (aqueous methanol, lit. ${ }^{17)} 183^{\circ} \mathrm{C}$ ), $67 \%$; and $N^{6}-(2$-phenylethyl)adenosine (4c), mp 166 $167^{\circ} \mathrm{C}$ (aqueous ethanol, lit. $\left.{ }^{18)} 165 \sim 167^{\circ} \mathrm{C}\right), 91 \%$. 6-Phenoxypurine (2a), mp $221 \sim 223^{\circ} \mathrm{C}$ (aqueous methanol, lit. ${ }^{19)} 217 \sim 218^{\circ} \mathrm{C}$ ) and 6benzyloxypurine (2b), $\mathrm{mp} 172 \sim 173^{\circ} \mathrm{C}$ (aqueous methanol, lit. ${ }^{20)} 171 \sim 172^{\circ} \mathrm{C}$ ) were prepared in $43 \%$ and $45 \%$ yields, respectively, by nucleophilic substitution of 6-chloro- purine with the corresponding sodium alkoxides. ${ }^{20)}$ The structures of the known compounds were confirmed by their IR,UV and ${ }^{1} \mathrm{H}-\mathrm{NMR}$ spectra. $N^{6}$-Benzyladenine (1b) was a product of Kohjin Co.

Bioassay. An Amaranthus betacyanin test was carried out by the method of Biddington and Thomas. ${ }^{21)}$ Cytokinin activity is expressed by $\mathrm{pC}_{0.1 \mu \mathrm{MBA}}$ (logarithm of the reverse of the concentration $(\mu \mathrm{M})$ at which the samples formed the same amount of betacyanin as that of $0.1 \mu \mathrm{M}$ BA). ${ }^{4}$

A germination test was made by using lettuce seeds (Great Lakes 366) at $31( \pm 1)^{\circ} \mathrm{C}$ for 4 days in the dark as reported ${ }^{4)}$ Similarly, cytokinin activity is expressed by $\mathrm{pE}_{50}$ (logarithm of the reverse of the concentration $(\mu \mathrm{M})$ for $50 \%$ germination).

A tobacco callus test was conducted as reported ${ }^{3,22)}$ and cytokinin activity is expressed by $\mathrm{pC}_{\mathrm{K}}$ (logarithm of the reverse of the concentration $(\mu \mathrm{M})$ at which the samples formed the same amount of callus (fresh weight) as $50 \%$ of the maximum yield of kinetin, a standard compound, after 30 days).

6-(2-Phenylethoxy)purine (2c). This compound was synthesized in a $78 \%$ yield by the method of Bowles et al. ${ }^{20)}$ Recrystallization from aqueous methanol gave a crystalline powder, mp $171 \sim 173^{\circ} \mathrm{C}$. IR $(\mathrm{KBr}) 3100(\mathrm{NH})$, $1610,1580(\mathrm{C}=\mathrm{N}, \mathrm{C}=\mathrm{C}) \mathrm{cm}^{-1}$; UV: $\lambda_{\max }^{\mathrm{pH} 1} 254(12,000)$, $\lambda_{\min }^{\mathrm{pH} 1} 221(4,270), \lambda_{\max }^{\mathrm{pH} 7} 252(11,900), \lambda_{\min }^{\mathrm{pH} 7} 218(3,640)$, $\lambda_{\max }^{\mathrm{pH} 13} 261 \quad(10,900), \quad \lambda_{\min }^{\mathrm{pH} 13} 231 \quad(3,000) \mathrm{nm} ;{ }^{1} \mathrm{H}-\mathrm{NMR}$ (DMSO- $\left.d_{6}\right) \delta: 3.12\left(2 \mathrm{H}, \mathrm{t}, J=7 \mathrm{~Hz}, \mathrm{Ph}-\mathrm{CH}_{2}\right), 4.74(2 \mathrm{H}, \mathrm{t}$, $\left.J=7 \mathrm{~Hz}, \mathrm{O}-\mathrm{CH}_{2}\right), 7.29(5 \mathrm{H}$, broad s, phenyl), $8.34(1 \mathrm{H}, \mathrm{s}$, $8-\mathrm{H}), 8.45(1 \mathrm{H}, \mathrm{s}, 2-\mathrm{H})$. Anal. Calcd. for $\mathrm{C}_{13} \mathrm{H}_{12} \mathrm{~N}_{4}$. $0.2 \mathrm{H}_{2} \mathrm{O}: \mathrm{C}, 64.03 ; \mathrm{H}, 5.13 ; \mathrm{N}, 22.97$. Found: $\mathrm{C}, 64.28$; $\mathrm{H}, 4.80 ; \mathrm{N}, 22.77 \%$.

6-(3-Phenylpropoxy)purine (2d). This compound was synthesized in a $65 \%$ yield and recrystallized from aqueous methanol to give plates, mp $121 \sim 123^{\circ} \mathrm{C}$. IR $(\mathrm{KBr}) 3050$ $(\mathrm{NH}), 1610,1590(\mathrm{C}=\mathrm{N}, \mathrm{C}=\mathrm{C}) \mathrm{cm}^{-1}$; UV: $\lambda_{\max }^{\mathrm{pH} 11} 254$ $(9,850), \lambda_{\min }^{\mathrm{pH} 1} 223(4,030), \lambda_{\max }^{\mathrm{pH} 7} 253(8,990), \lambda_{\min }^{\mathrm{pH} 7} 222$ $(3,950), \lambda_{\max }^{\mathrm{pH} 13} 261(10,600), \lambda_{\min }^{\mathrm{pH} 13} 232(2,790) \mathrm{nm} ;{ }^{1} \mathrm{H}-$ NMR (DMSO- $\left.d_{6}\right) \delta: 2.10\left(2 \mathrm{H}, \mathrm{m}, \mathrm{C}-\mathrm{CH}_{2}-\mathrm{C}\right), 2.77(2 \mathrm{H}, \mathrm{t}$, $\left.J=7 \mathrm{~Hz}, \mathrm{Ph}-\mathrm{CH}_{2}\right), 4.51\left(2 \mathrm{H}, \mathrm{t}, J=7 \mathrm{~Hz}, \mathrm{O}-\mathrm{CH}_{2}\right), 7.24$ $(5 \mathrm{H}$, broad s, phenyl), $8.34(1 \mathrm{H}, \mathrm{s}, 8-\mathrm{H}), 8.45(1 \mathrm{H}, \mathrm{s}, 2-\mathrm{H})$. Anal. Calcd. for $\mathrm{C}_{14} \mathrm{H}_{14} \mathrm{~N}_{4} \cdot 0.2 \mathrm{H}_{2} \mathrm{O}: \mathrm{C}, 65.20 ; \mathrm{H}, 5.63 ; \mathrm{N}$, 21.72. Found: $\mathrm{C}, 65.02 ; \mathrm{H}, 5.35 ; \mathrm{N}, 21.46 \%$.

6-(4-Phenylbutoxy)purine (2e). This compound was similarly prepared. After silica gel column chromatography by eluting with hexane-ethyl acetate $(1: 1)$ and following by removal of the solvents, $2 \mathbf{e}$ was obtained as a colorless powder, $\mathrm{mp} 116 \sim 118^{\circ} \mathrm{C}$, in an $84 \%$ yield. Recrystallization from benzene afforded a crystalline powder of the same melting point. IR (KBr) $3080(\mathrm{NH}), 1590$, $1570(\mathrm{C}=\mathrm{N}, \mathrm{C}=\mathrm{C}) \mathrm{cm}^{-1}$; UV: $\lambda_{\max }^{\mathrm{pH} 1} 254(9,710), \lambda_{\min }^{\mathrm{pH} 1}$ $223(3,580), \lambda_{\max }^{\mathrm{pH} 7} 252(9,390), \lambda_{\min }^{\mathrm{pH} 7} 222(3,030), \lambda_{\max }^{\mathrm{pH} 13} 254$ 
(9,710), $\lambda_{\min }^{\mathrm{pH} 13} 232(2,310) \mathrm{nm} ;{ }^{1} \mathrm{H}-\mathrm{NMR}$ (DMSO- $\left.d_{6}\right) \delta:$ $1.5 \sim 2.0\left(4 \mathrm{H}, \mathrm{m}, \mathrm{C}-\mathrm{CH}_{2}-\mathrm{CH}_{2}-\mathrm{C}\right), 2.65(2 \mathrm{H}$, broad t, $J=$ $\left.7 \mathrm{~Hz}, \mathrm{Ph}-\mathrm{CH}_{2}\right), 4.56\left(2 \mathrm{H}\right.$, broad t, $\left.J=7 \mathrm{~Hz}, \mathrm{O}-\mathrm{CH}_{2}\right), 7.20$ (5H, broad s, phenyl), $8.34(1 \mathrm{H}, \mathrm{s}, 8-\mathrm{H}), 8.46(1 \mathrm{H}, \mathrm{s}, 2-\mathrm{H})$. Anal. Calcd. for $\mathrm{C}_{15} \mathrm{H}_{16} \mathrm{~N}_{4} \mathrm{O}: \mathrm{C}, 67.15 ; \mathrm{H}, 6.01 ; \mathrm{N}, 20.88$. Found: C, 67.01; H, 5.77; N, 20.58\%.

2-Methyl-4-anilinopyrido[3,4-d]pyrimidine (3a). A mixture of 2-methyl-4-chloropyrido[3,4-d]pyrimidine ${ }^{7)}(180$ $\mathrm{mg}, 1.0 \mathrm{mmol})$, aniline $(162 \mathrm{mg}, 2.0 \mathrm{mmol})$ and ethanol $(20 \mathrm{ml})$ was stirred at $40 \sim 50^{\circ} \mathrm{C}$ for a few minutes. The solution was concentrated to a small volume, diluted with water and cooled in an ice bath. The resultant crystals were collected, washed with aqueous ethanol and dried. The crude product was recrystallized from the solvent to give fine needles, $\mathrm{mp} 232 \sim 233^{\circ} \mathrm{C}(232 \mathrm{mg}, 98 \%)$. IR (KBr) $3300(\mathrm{NH}), 1620,1600,1570(\mathrm{C}=\mathrm{N}, \mathrm{C}=\mathrm{C}) \mathrm{cm}^{-1}$; UV: $\lambda_{\max }^{\mathrm{pH} 1} 340(11,600), 285(5,990), \lambda_{\max }^{\mathrm{pH} 7} 344(9,800), 289$ $(9,030), \quad \lambda_{\max }^{\mathrm{pH} 12} 344(9,700), 289(9,060) \mathrm{nm} ;{ }^{1} \mathrm{H}-\mathrm{NMR}$ $\left(\mathrm{DMSO}-d_{6}\right) \delta: 2.57\left(3 \mathrm{H}, \mathrm{s}, \mathrm{CH}_{3}\right), 7.2 \sim 8.0(5 \mathrm{H}, \mathrm{m}$, phenyl), $8.42(1 \mathrm{H}, \mathrm{dd}, J=5,1 \mathrm{~Hz}, 5-\mathrm{H}), 8.67(1 \mathrm{H}, \mathrm{d}, J=$ $5 \mathrm{~Hz}, 6-\mathrm{H}), 9.10(1 \mathrm{H}$, broad s, 8-H), $9.93(1 \mathrm{H}, \mathrm{s}, \mathrm{NH})$. Anal. Calcd. for $\mathrm{C}_{14} \mathrm{H}_{12} \mathrm{~N}_{4}$ : C, 71.16; H, 5.12; N, 23.72. Found: C, 71.17 ; H, 5.19; N, 23.60\%.

2-Methyl-4-benzylaminopyrido[3,4-d]pyrimidine (3b). The UV data for $\mathbf{3 b}$ were not reported in a previous paper. ${ }^{7)} \mathrm{UV}: \lambda_{\max }^{\mathrm{pH} 1} 338(8,810), 324(11,400), 275(7,630)$, $\lambda_{\max }^{\mathrm{pH} 7} 330.5(7,700), 282.5(9,430), \lambda_{\max }^{\mathrm{pH} 13} 331(7,570), 282.5$ $(9,500) \mathrm{nm}$.

2-Methyl-4-(2-phenylethylamino)pyrido [3,4-d]pyrimidine (3c). This compound, $\mathrm{mp} 118 \sim 119^{\circ} \mathrm{C}$ (from aqueous ethanol), was synthesized in a quantitative yield. IR $(\mathrm{KBr}) 3310(\mathrm{NH}), 1615,1580(\mathrm{C}=\mathrm{N}, \mathrm{C}=\mathrm{C}) \mathrm{cm}^{-1}$; UV: $\lambda_{\max }^{\mathrm{pH} 1} 338(9,080), 324.5(11,000), 284(7,250), \lambda_{\max }^{\mathrm{pH} 7} 332$ $(8,020), 284.5(9,020), \lambda_{\max }^{\mathrm{pH} 13} 332(7,930), 284.5(9,220)$ nm; ${ }^{1} \mathrm{H}-\mathrm{NMR}$ (DMSO- $\left.d_{6}\right) \delta: 2.49\left(3 \mathrm{H}, \mathrm{s}, \mathrm{CH}_{3}\right), 2.97$ $\left(2 \mathrm{H}, \mathrm{t}, J=7 \mathrm{~Hz}, \mathrm{Ph}-\mathrm{CH}_{2}\right), 3.75(2 \mathrm{H}, \mathrm{q}, J=7 \mathrm{~Hz}, \mathrm{~N}-$ $\left.\mathrm{CH}_{2}\right), 7.31(5 \mathrm{H}$, broad s, phenyl), $8.06(1 \mathrm{H}, \mathrm{dd}, J=5,1 \mathrm{~Hz}$, $5-\mathrm{H}), 8.52(1 \mathrm{H}, \mathrm{d}, J=5 \mathrm{~Hz}, 6-\mathrm{H}), 8.57(1 \mathrm{H}$, broad s, NH), $8.99\left(1 \mathrm{H}\right.$, broads, 8-H). Anal. Calcd. for $\mathrm{C}_{16} \mathrm{H}_{16} \mathrm{~N}_{4}$. $2.0 \mathrm{H}_{2} \mathrm{O}: \mathrm{C}, 63.98 ; \mathrm{H}, 6.71 ; \mathrm{N}, 18.65$. Found: $\mathrm{C}, 64.07 ; \mathrm{H}$, $6.66 ; \mathrm{N}, 18.66 \%$.

2-Methyl-4-(3-phenylpropylamino)pyrido[3,4-d]pyrimidine (3d). This compound, $\mathrm{mp} 113 \sim 114^{\circ} \mathrm{C}$ (from aqueous ethanol), was synthesized in a $43 \%$ yield. IR ( $\mathrm{KBr}$ ) $3240(\mathrm{NH}), 2960,2870(\mathrm{CH}), 1610,1580(\mathrm{C}=\mathrm{N}, \mathrm{C}=\mathrm{C})$ $\mathrm{cm}^{-1}$; UV: $\lambda_{\max }^{\mathrm{pH} 1} 338(9,030), 324.5$ (7,870), $276(7,190)$, $\lambda_{\max }^{\mathrm{pH} 7} 332.5(8,010), 285 \quad(9,150), \lambda_{\max }^{\mathrm{pH} 13} 332.5 \quad(7,870)$, $285(9,160) \mathrm{nm} ;{ }^{1} \mathrm{H}-\mathrm{NMR}$ (DMSO- $\left.d_{6}\right) \delta: 1.97(2 \mathrm{H}, \mathrm{m}, \mathrm{C}-$ $\left.\mathrm{CH}_{2}-\mathrm{C}\right), 2.50\left(3 \mathrm{H}, \mathrm{s}, \mathrm{CH}_{3}\right), 2.68(2 \mathrm{H}, \mathrm{t}, J=7 \mathrm{~Hz}, \mathrm{Ph}-$ $\left.\mathrm{CH}_{2}\right), 3.60\left(2 \mathrm{H}, \mathrm{q}, J=6 \mathrm{~Hz}, \mathrm{~N}-\mathrm{CH}_{2}\right), 7.27(5 \mathrm{H}$, broads, phenyl), 8.24 (1H, dd, $J=5,1 \mathrm{~Hz}, 5-\mathrm{H}), 8.60(1 \mathrm{H}, \mathrm{d}, J=$ $5 \mathrm{~Hz}, 6-\mathrm{H}), 9.02(1 \mathrm{H}$, broad s, 8-H), $9.13(1 \mathrm{H}$, broad, $\mathrm{NH})$. Anal. Calcd for $\mathrm{C}_{17} \mathrm{H}_{18} \mathrm{~N}_{4} \cdot 2.0 \mathrm{H}_{2} \mathrm{O}: \mathrm{C}, 64.95 ; \mathrm{H}, 7.05 ; \mathrm{N}$,
17.82. Found: C, $64.93 ; \mathrm{H}, 6.76 ; \mathrm{N}, 17.64 \%$.

$N^{6}$-3-(Phenylpropyl)adenosine (4d). A mixture of 6chloro-9- $\beta$-D-ribofuranosylpurine $\quad(287 \mathrm{mg}, \quad 1.0 \mathrm{mmol})$, 3 -phenylpropylamine $(155 \mathrm{mg}, 1.2 \mathrm{mmol})$, triethylamine $(0.5 \mathrm{ml})$ and 1-butanol $(5 \mathrm{ml})$ was refluxed for $1.5 \mathrm{hr}$. The mixture was dried, dissolved in ethanol and allowed to crystallize in a refrigerator $\left(5^{\circ} \mathrm{C}\right)$ to give colorless needles, $\mathrm{mp} 124 \sim 126^{\circ} \mathrm{C}\left(348 \mathrm{mg}, 88^{\circ} \%\right.$ ). IR (KBr) 3350, 3200 (NH, $\mathrm{OH}), 1630(\mathrm{C}=\mathrm{N}), 1140,1100,1065(\mathrm{C}-\mathrm{O}), 760,705$ (phenyl) $\mathrm{cm}^{-1}$; UV: $\lambda_{\max }^{\mathrm{pH} 1} 263(14,700), \lambda_{\max }^{\mathrm{pH} 7} 267(15,800)$, $\lambda_{\max }^{\mathrm{pH} 13} 267(14,700) \mathrm{nm} ;{ }^{1} \mathrm{H}-\mathrm{NMR}$ (DMSO- $\left.d_{6}\right) \delta: 1.87$ $\left(2 \mathrm{H}, \mathrm{m}, \mathrm{C}-\mathrm{CH}_{2}-\mathrm{C}\right), 2.63\left(2 \mathrm{H}\right.$, broad t, $\left.J=7 \mathrm{~Hz}, \mathrm{Ph}-\mathrm{CH}_{2}\right)$, $3.5\left(2 \mathrm{H}, \mathrm{m}, \mathrm{N}-\mathrm{CH}_{2}\right.$, overlapped by HOD signal), 3.52 and $3.65\left(2 \mathrm{H}, \mathrm{m}, 5^{\prime}-\mathrm{H}\right), 3.98\left(1 \mathrm{H}, \mathrm{m}, 4^{\prime}-\mathrm{H}\right), 4.16\left(1 \mathrm{H}, \mathrm{m}, 3^{\prime}-\mathrm{H}\right)$, $4.61\left(1 \mathrm{H}\right.$, broad t, $\left.J=6 \mathrm{~Hz}, 2^{\prime}-\mathrm{H}\right), 5.92\left(1 \mathrm{H}, \mathrm{d}, J=6 \mathrm{~Hz}, 1^{\prime}\right.$ $\mathrm{H}), 7.2(5 \mathrm{H}$, broad s, phenyl), $7.88(1 \mathrm{H}$, broad t, $J=6 \mathrm{~Hz}$, NH), $8.22(1 \mathrm{H}, \mathrm{s}, 8-\mathrm{H}), 8.33(1 \mathrm{H}, \mathrm{s}, 2-\mathrm{H})$. Anal. Calcd. for $\mathrm{C}_{19} \mathrm{H}_{23} \mathrm{~N}_{5} \mathrm{O}_{4} \cdot 0.5 \mathrm{H}_{2} \mathrm{O}: \mathrm{C}, 57.86 ; \mathrm{H}, 6.13 ; \mathrm{N}, 17.76$. Found: C, $57.42 ; \mathrm{H}, 6.23 ; \mathrm{N}, 17.58 \%$.

$N^{6}$-(4-Phenylbutyl)adenosine (4e). This compound, $\mathrm{mp}$ $123 \sim 124^{\circ} \mathrm{C}$ (from ethanol) was synthesized in an $86 \%$ yield. IR ( KBr) 3350, $3230(\mathrm{NH}, \mathrm{OH}), 1630(\mathrm{C}=\mathrm{N}), 1140$, 1090, 1070 (C-O), 760, 710 (phenyl) $\mathrm{cm}^{-1}$; UV: $\lambda_{\max }^{\mathrm{pH} 1} 263$ $(16,400), \lambda_{\max }^{\mathrm{pH} 7} 266(15,100), \lambda_{\max }^{\mathrm{pH} 13} 267(15,200) \mathrm{nm} ;{ }^{1} \mathrm{H}-$ NMR (DMSO- $\left.d_{6}\right) \delta: 1.5 \sim 1.8\left(4 \mathrm{H}, \mathrm{m}, \mathrm{C}-\mathrm{CH}_{2}-\mathrm{CH}_{2}-\mathrm{C}\right)$, $2.60\left(2 \mathrm{H}, \mathrm{Ph}-\mathrm{CH}_{2}\right.$, overlapped by DMSO- $d_{6}$ signal), 3.5 (2H, m, N- $\mathrm{CH}_{2}$, overlapped by HOD signal), 3.53 and $3.66\left(2 \mathrm{H}, \mathrm{m}, 5^{\prime}-\mathrm{H}\right), 3.98\left(1 \mathrm{H}, \mathrm{m}, 4^{\prime}-\mathrm{H}\right), 4.16\left(1 \mathrm{H}, \mathrm{m}, 3^{\prime}-\mathrm{H}\right)$, $4.63\left(1 \mathrm{H}, \mathrm{m}, 2^{\prime}-\mathrm{H}\right), 5.93\left(1 \mathrm{H}, \mathrm{d}, J=6 \mathrm{~Hz}, 1^{\prime}-\mathrm{H}\right), 7.25(5 \mathrm{H}$, broad s, phenyl), $7.88(1 \mathrm{H}$, broad t, $J=7 \mathrm{~Hz}, \mathrm{NH}), 8.23$ $(1 \mathrm{H}, \mathrm{s}, 8-\mathrm{H}), 8.32(1 \mathrm{H}, \mathrm{s}, 2-\mathrm{H})$. Anal. Calcd. for $\mathrm{C}_{20} \mathrm{H}_{25} \mathrm{~N}_{5} \mathrm{O}_{4} \cdot 0.5 \mathrm{H}_{2} \mathrm{O}: \mathrm{C}, 68.81 ; \mathrm{H}, 6.42 ; \mathrm{N}, 17.15$. Found: C, $59.24 ; \mathrm{H}, 6.10 ; \mathrm{N}, 17.14 \%$.

Acknowledgment. The authors are grateful to $\mathrm{Mr}$. $\mathrm{H}$. Mizutani for his technical assistance.

\section{REFERENCES}

1) E. J. Ariëns, "Drug Design," Vol. 1. ed by E. J. Ariëns, Academic Press, New York, 1971, p. 128.

2) C. G. Raison and O. D. Standen, Brit. J. Pharmacol., 10, 191 (1955).

3) H. Iwamura, T. Fujita, S. Koyama, K. Koshimizu and Z. Kumazawa, Phytochemistry, 19, 1309 (1980).

4) S. Koyama, Z. Kumazawa, N. Kashimura and R. Nishida, Agric. Biol. Chem., 49, 1859 (1985).

5) S. Nishikawa, Z. Kumazawa, N. Kashimura, H. Mizutani and H. Kondo, Agric. Biol. Chem., 49, 3353 (1985).

6) S. Nishikawa, S. Maki, Z. Kumazawa and N. Kashimura, Bull. Fac. Agric. Mie Univ., 69, 163 (1984).

7) S. Nishikawa, Z. Kumazawa, N. Kashimura, S. Maki and Y. Nishikimi, Agric. Biol. Chem., 50, 495 
(1986).

8) S. Kuraishi, Sci. Papers, Coll. Gen. Ed. Univ. Tokyo, 9, 67 (1959).

9) C. G. Skinner, J. R. Claybrook, F. Talbert and W. Shive, Plant Physiol., 32, 117 (1957).

10) T. R. Henderson, C. R. Frihart, N. J. Leonard, R. Y. Schmitz and F. Skoog, Phytochemistry, 14, 1687 (1975).

11) T. Hashizume, S. Sakai, T. Sugiyama and S. Matsubara, Phytochemistry, 15, 1813 (1976).

12) S. Koyama, Y. Nishikimi, Z. Kumazawa and N. Kashimura, Abstracts of Papers, 5th International Congress of Pesticide Chemistry, Kyoto, August, 1982, IId-17.

13) U. K. Conrad, Biochem. Physiol. Pflanzen, 162, 327 (1971).

14) T. Endo, M. Ito and T. Namiki, J. Chem. Soc.,
Chem. Commun., 1985, 933.

15) G. B. Elion, E. Burgi and G. H. Hitchings, J. Am. Chem. Soc., 74, 411 (1952).

16) W. Shive and C. G. Skinner, U. S. Pat., 2,966,488 (1960).

17) M. H. Fleysher, A. Bloch, M. T. Hakala and C. A. Nichol, J. Med. Chem., 12, 1056 (1969).

18) H. Vorbrüggen and K. Krolikiewicz, Liegigs Ann. Chem., 1976, 745.

19) J. H. Keck, Jr., R. A. Simpson and J. L. Lewis and R. K. Robins, J. Med. Chem., 6, 471 (1963).

20) W. A. Bowles, F. H. Schneider, J. L. Lewis and R. K. Robins, J. Med. Chem., 6, 471 (1963).

21) N. L. Biddington and T. H. Thomas, Planta, 111, 183 (1973).

22) E. M. Linsmaier and F. Skoog, Physiol. Plant., 18, 100 (1965). 